\title{
DEVELOPMENT OF MARBLE BEEF TECHNOLOGY
}

\author{
Ruslan Omarov $^{1}$, Ivan Gorlov ${ }^{2}$, Vladislav Zakotin ${ }^{1}$, Sergei Shlykov ${ }^{1}$ \\ ${ }^{1}$ Stavropol State Agrarian University, Russia; ${ }^{2}$ Volga Research Institute of Production \\ and Processing of Meat and Dairy Products, Russia \\ doooctor@yandex.ru, scopush@gmail.com, shlykovsn@gmail.com
}

\begin{abstract}
Marble beef technology was tested on the bulls of Kazakh white breed (Zavolzhsky type), because they have genetic predisposition to formation fatty streaks. For the experiment 3 groups of 10 calves of the age of 10 months were formed. The experiment lasted for 8 months. The calves of the control group received basic feed, I group - at the basic diet were enhanced by $180 \mathrm{~g}$ of cattle cake, II - $180 \mathrm{~g}$ fuzz of pumpkin seeds. The nutritional value of feed for testing calves was calculated to receive an average daily gain of live weight on the level of 1100-1200 g. The basic feed for testing calves depending on their age consisted from 2.0 to $3.5 \mathrm{~kg}$ hay of cereal and pulses, 9.0-15.0 kg of haylage, 3.1-4.0 kg compound feed and 0.4 kg molasses beet. For development of the marble beef technology evaluation of the exterior and dynamics of the daily gain of animals was carried out. Varietal composition of the carcass, deposition, localization, and the quality of adipose tissue were assessed. Analysis of the data has revealed that introduction into feed the cattle cake and fuzz of pumpkin seeds allows to increase by $29.8 \mathrm{~kg}$ gain and obtain beef of A3 category by the standard B.M.S. (Beef Marbling standard).
\end{abstract}

Keywords: marble beef, meat, Kazakh white breed.

\section{Introduction}

It is not a secret that marbled beef is recognized worldwide as royal dish: sweet taste of this meat is provided by a special technology of livestock, which allows to reach the tender meat scraps. And in this issue, each country and even each manufacturer, have their secrets: some water periodically steers with special beers, others spend massage courses for the cattle, and others without interruption "twist" to overtures of Bach and Chopin, and all this to get in the future better marble beef, which later becomes refined dish. However, this kind of meat got the name "marbled beef" because in appearance it is very similar to marble: small and thin veins plexus fatty layers resemble marble. These unpretentious veins in the beef produced in the muscle tissue of young bulls are created by special and difficult growing technology. It is because of minor fatty layers of meat why beef has unique delicate taste that is appreciated by many connoisseurs worldwide.

The food industry development has subordinated the beef production to the laws of economic benefits. In meat stock farming, the herbal fattening complements the cereals. Cattle that are raised on grain will have more marbling than grass-fed beef. This is fairly intuitive since you can imagine how difficult it would be to get fat by eating grass. By grain feeding, premium beef "marbled meat" can be obtained, but such raw material contains a lot of saturated fatty acids. The grains, which mainly contain omega- 6 , are not natural food for herbivores, and it leads to skewed omega-3 to omega- 6 , the molecule which is stable and harmful in large quantities, causing a variety of inflammation, leads to thickening of blood, development allergies, blood clots, narrowing of blood vessels, diabetes and cancer. The grass-fed beef contains less external and internal fat and has the perfect ratio of omega-3 to omega-6, which should be from 1:1 to 1:4. Therefore, the development of beef marble technology of high quality is an urgent task and has a high practical value.

\section{Materials and methods}

The experiment was made with 3 groups of 10 calves Kazakh white-headed breed (Zavolzhskiy type) in the age of ten months. The duration of the experiment was 8 months [1-4]. The control animals were fed by basic feed, I group - in addition received $180 \mathrm{~g}$ cake of pumpkin seeds, II group $180 \mathrm{~g}$ fuzz of pumpkin seeds. The studied animals were kept on a leash. The nutritional value of feed strategy designed for a daily average gain of the live mass was at least 1100-1200 g. The main feed was differentiated in accordance with age-related needs. The basic feed during the experiment consisted of 2.0-3.5 kg of green grass-legume hay, 9.0-15.0 kg of haylage, 3.1-4.0 kg compound feed, $0.4 \mathrm{~kg}$ sugar beet molasses, and essential mineral premixes.

$\mathrm{pH}$ was determined $24 \mathrm{~h}$ post-mortem $(\mathrm{pH} 24)$ in LT between the 9th and 10th rib using a Radiometer pHM201 pH meter with an insertion-electrode ME 6.0226.100 (Metrohm, Herisau, 
Switzerland). Temperature was measured at the same location using a Testo 110 digital thermometer. Calibration of the $\mathrm{pH}$ meter was performed at the same temperature as the internal temperature of LT at $24 \mathrm{~h}$ postmortem [5].

Chemical analyses to determine the content of protein, fat, water and minerals (ashes) of processed meat products are carried out to establish the nutritive and economic value of the products. Samples of the meat product are finely ground and weighed accurately for each respective chemical analysis.

The determination of the moisture content (or water content) is done by drying an appropriate amount of the sample. The difference in weight between the fresh and dried samples represents the water content. For rapid determination of the moisture content a microwave oven is useful.

The protein content is determined at laboratory level by using the Kjeldahl method, where meat products are digested by acid to obtain the nitrogen compounds and then distilled and titrated to determine nitrogen quantitatively, with which the protein component can be calculated. In a simplified approach protein is not chemically determined, but can be calculated (approximately) as the remaining component, after water, fat and ashes content has been determined and subtracted from $100 \%$.

The defatted samples are then used for ash analysis by subjecting to the temperature of $+600{ }^{\circ} \mathrm{C}$ in a muffle furnace for two hours. The weight of the ash is used to calculate the mineral content in $\%$ (weight of ash, divided by total sample weight, multiplied by 100).

Texture measurements. Frozen samples were thawed overnight and equilibrated to room temperature $\left(25^{\circ} \mathrm{C}\right)$ prior to texture analysis.

Warner-Bratzler shear force was measured on raw and cooked meat after 10 days of ageing postmortem. Slices were cooked in a water bath at $80^{\circ} \mathrm{C}$ until $75^{\circ} \mathrm{C}$ internal temperature was reached, cooled for $45 \mathrm{~min}$ in running tap water and stored at $4{ }^{\circ} \mathrm{C}$ until analysis. For each animal, shear force measurements of raw and cooked samples were performed on 10 blocks $(2 \mathrm{~cm}$ in length and $1 \mathrm{~cm}$ by 1 $\mathrm{cm}$ of cross section), and cut perpendicular to the fibre direction. The maximum force required to shear through the sample using a triangular-shaped Warner-Bratzler shear blade was determined. The blade was mounted on a 1011 Instron machine, running at a crosshead speed of $100 \mathrm{~mm} / \mathrm{min}$.

The compression test was carried out on raw meat aged 10 days as described by Campo et al. [6]. Samples, $1 \mathrm{~cm} 2$ in cross section, were cut with muscle fibres parallel to the longitudinal axis of the sample and were analysed using a modified compression device that avoids transversal elongation of the sample. Stress at $80 \%$ of maximum compression was assessed using an Instron 4301 machine with the probe speed of $150 \mathrm{~mm} \cdot \mathrm{min}^{-1}$. Compression of raw meat at high strain values can be used to measure the strength of the connective tissue in raw meat [7].

Fat was extracted by the method of Folch, Lees, and Stanley [8] separated into neutral lipid and phospholipid, methylated, separated by GLC and the individual peaks identified and quantified as described in detail by Scollan et al. [9]. Total lipid content, was taken as the sum of the neutral lipid and phospholipid fractions.

The marble scores were carried out by the New Beef Marbling Standard from 2008 - JMGA.

All data were analyzed by the method of least squares means using the mixed procedure in SAS Software (SAS Institute Inc., Cary, NC, USA). Significant differences between least squares means were evaluated using the option Pdiff, with no corrections due to multiple comparisons. From Proc GLM (SAS), the Manova statement with the Printe option was used to calculate Partial Correlation Coefficients $(\rho)$ from the error SSCP Matrix (error sum of squares and cross-products matrix). The data were considered significantly different if $\mathrm{Pb} 0.05$.

\section{Results and discussion}

Introduction into feed pumpkin oil cake and fuzz had positive influence on formation of the physiological parameters of animals. The height at the withers of the animals of the I-st and II-nd groups prevailed above control by $0.7 \mathrm{~cm}$ (for the I-st group) and $1.1 \mathrm{~cm}$ (II), by the height of the highest point sacrum, the advantage was for the I-st group $1.1 \mathrm{~cm}$ and $1.5 \mathrm{~cm}$ for the II-nd group. The difference in the breast width was 1.3 (between I and control) and $1.5 \mathrm{~cm}$ (between II and control), the depth of chest 2.2 (between I and control) and $2.5 \mathrm{~cm}$ (between the II and control), the width of butt to 
outer corners of Ilium by 1.8 (between I and control) and $2 \mathrm{~cm}$ (between the II and control), the width in the hip joints by 0.4 (between I and control) and $0.7 \mathrm{~cm}$ (between the II and control), the semicircumference of the backside by 2.5 (between I and control) and $3.2 \mathrm{~cm}$ (between the II and control). It was established that the index blockiness and massiveness were more from bulls of the I-st and II-nd experimental groups above control by 3.50 to 3.67 (index blockiness) and by 4.41 and 4.25 (index massiveness). The live weight of the calves at the beginning of the experiment ranged within narrow limits from to $284.47283 .5 \mathrm{~kg}$. In the age of 14 months, the animals from groups I and II by live weight were superior to control on 10.1 and $15 \mathrm{~kg}$, at the age of 16 months by 15.7 and $22.8 \mathrm{~kg}$, at the age of 18 months by 19.6 and $29.5 \mathrm{~kg}$.

The calves from the experimental groups had a higher growth rate, average daily gain from 10 to 18 months of age in the animals of groups I and II was higher compared to the control by 85.5 and 124.3 g. Higher intensity gain of live weight the calves from the experimental groups confirmed by indicators of absolute and relative gains. Live weight of young animals selected for slaughter is significantly varied depending on the composition of their feed during feeding. By this indicator the animals from the I-st and II-nd experimental groups prevailed over control by $21.1 \mathrm{~kg}$ and $31.4 \mathrm{~kg}$.

By mass carcass meat the animals from the I-st and II-nd experimental groups exceeded control by $21.9 \mathrm{~kg}$ and $30.2 \mathrm{~kg}$, that affected to yield of carcasses, this was 1.78 and $2.19 \%$. The carcass meat of the animals in groups I and II according to the results of control slaughter exceeded the control by 21.9 and $30.2 \mathrm{~kg}$, the yield was higher by 1.8 and $2.2 \%$. Higher fat content in feed of calves causes more internal fat in their bodies (by 3.5 and $7.1 \mathrm{~kg}$ ) relative to control group. Animals that consumed feed with cake and fuzz of pumpkin seeds had higher carcass yield in relation to control by 4.1 and $5.1 \%$, carcass weight by 25.4 and $37.3 \mathrm{~kg}$, large mass of flesh by 23.3 and $33.1 \mathrm{~kg}$, its yield by 1.7 and $2.5 \%$. The research revealed higher fat content in muscles from the experimental animals relative to control by $3.3 \%$ and $4.3 \%$.

The study of the chemical composition revealed prevalence of the animals from the experimental groups over individuals from control (Fig. 1).

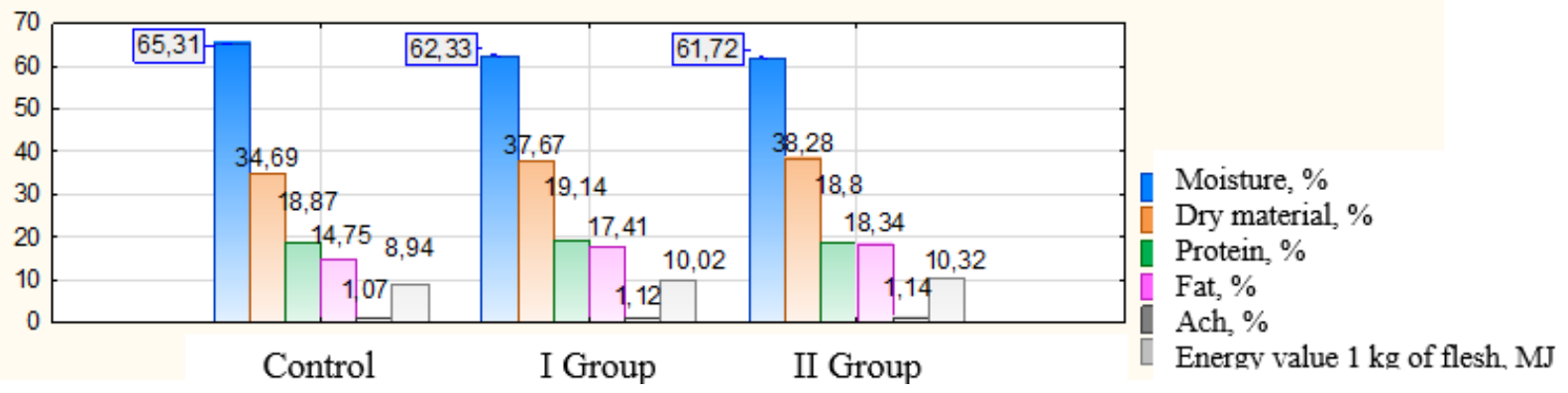

Fig. 1. Chemical composition of average sample raw meat

Determination of the "marbling" degree of meat was carried out by the B. M. S. (Beef Marbling standard) (Fig. 2).

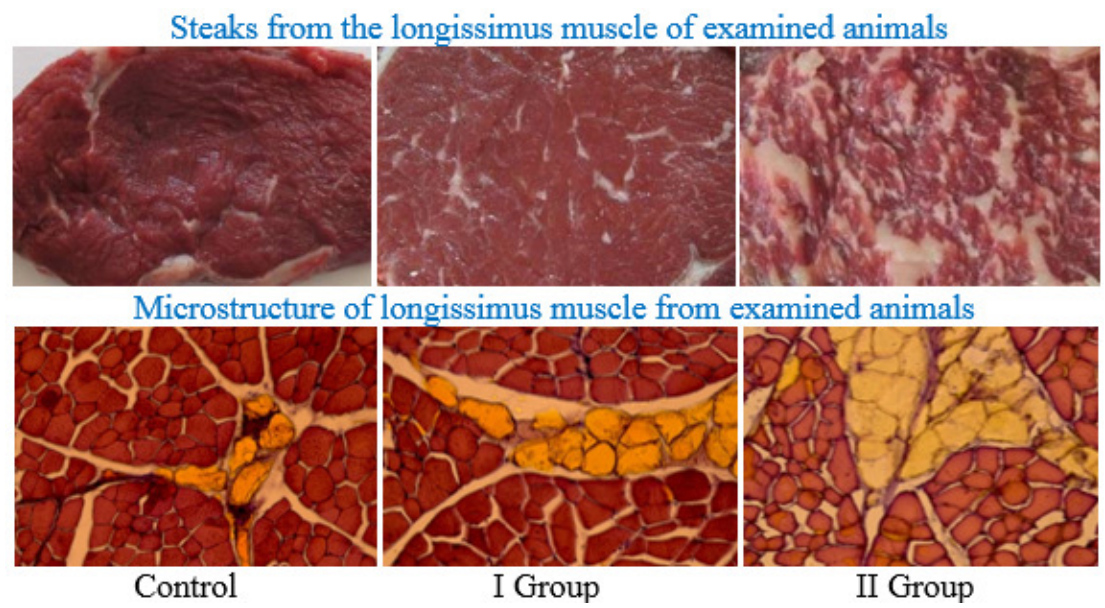

Fig. 2. Steaks from longissimus muscle and microstructure 
Marble beef from the animals of the I group has grade 3, the animals of the II group has grade 5 (the highest) by the Beef Marbling Standard. High-fat content in the longissimus muscle from the calves of the I-st and II-nd experimental groups is reflected in the energy value, the advantage made up 1.31 MJ and 1.54 MJ (Table 1).

Area of deposition adipose tissue in the studied animals

Table 1

\begin{tabular}{|l|c|c|c|c|c|c|}
\hline \multirow{2}{*}{\multicolumn{1}{|c|}{ Indicator }} & \multicolumn{6}{c|}{ Group } \\
\cline { 2 - 7 } & \multicolumn{2}{|c|}{ Control } & \multicolumn{2}{c|}{ I } & \multicolumn{2}{c|}{ II } \\
\cline { 2 - 7 } & $\mathrm{kg}$ & $\%$ & $\mathrm{~kg}$ & $\%$ & $\mathrm{~kg}$ & $\%$ \\
\hline Intermuscular adipose tissue & 8.08 & 25.9 & 9.63 & 26.3 & 11.53 & 26.8 \\
\hline Internal fat & 15.72 & 50.4 & 19.21 & 52.5 & 22.85 & 53.1 \\
\hline Subcutaneous adipose tissue & 7.39 & 23.7 & 7.76 & 21.2 & 8.65 & 20.1 \\
\hline Total & 31.19 & 100.0 & 36.6 & 100.0 & 43.03 & 100.0 \\
\hline
\end{tabular}

\section{Conclusions}

1. Introduction of oil cake and fuzz pumpkin seeds in feed promotes the growth of the live weight of the calves at 18 months of age by $21.1 \mathrm{~kg}$ and $31.4 \mathrm{~kg}$ compared with control.

2. The experimental animals were characterized by the best indicators of the slaughter qualities, flesh of the meat content increased by 23.3 and $33.1 \mathrm{~kg}$, and the fat content by $3.3 \%$ and $4.3 \%$.

3. The grade of marble beef by the Beef Marbling Standard for group I was 3 and for the animals of group II it was 5 (the highest).

4. The calculations revealed that introduction into the feed for calves oil cake and fuzz of pumpkin seed was economically feasible. The absolute gain of the animals from the experimental groups exceeded the control by 20.5 and $29.8 \mathrm{~kg}$.

\section{References}

1. Sadovoy V., Omarov R., Shlykov S., Shchedrina T. Assessment compliance of qualitative food characteristics to standard requirements. 15th International Scientific Conference on Engineering for Rural Development, May 25-27, 2016, Jelgava, Latvia, pp. 360-363.

2. Albertí P., Panea B., Sañudo C., Olleta J. L., Ripoll G., Ertbjerg P., et al. Live weight, body size and carcass characteristics of young bulls of fifteen European breeds. Livestock Science, vol. 114, 2008, pp. 19-30.

3. Barker B.P., Mies W.L., Turner J.W., Lunt D.K., Smith S.B. Influence of production system on carcass characteristics of F1 Wagyu $\times$ Angus steers and heifers. Meat Science, vol. 41, 1995, pp. 1-5.

4. Barkhouse K.L., VanVleck L.D., Cundiff L.V., Koohmaraie M., Lunstra D.D., Crouse, J.D. Prediction of breeding values for tenderness of market animals from measurements on bulls. Journal of Animal Science, vol. 74, 1996, pp. 2612-2621.

5. Karlsson A.H., Rosenvold K. The calibration temperature of $\mathrm{pH}$-glass electrodes: Significance for meat quality classification. Meat Science, vol. 62, 2002, pp. 497-501.

6. Campo M.M., Santolaria P., Sañudo C., Lepetit J., Olleta J.L., Panea B., et al. Assessment of breed type and ageing time effects on beef meat quality using two different texture devices. Meat Science, vol. 55, 2000, pp. 371-378.

7. Lepetit J., Culioli J. Mechanical properties of meat. Meat Science, vol. 36, 1994, pp. 203-237.

8. Folch J., Lees M., Stanley G.H.S. A simple method for the isolation and purification of lipids from animal tissues. The Journal of Biological Chemistry, vol. 226, 1957, pp. 497-509.

9. Scollan N.D., Choi N.J., Kurt E., Fisher A.V., Enser M., Wood J.D. Manipulating the fatty acid composition of muscle and adipose tissue in beef cattle. The British Journal of Nutrition, vol. 85, 2001, pp. 115-124. 